Rev. Krzysztof Trębski

University of Trnava

DOI: 10.15290/rtk.2021.20.10

iD $0000-0003-0115-5787$

\title{
Grief and Mourning During the COVID-19 Pandemic: A Psychological and Pastoral Perspective
}

This article considers the difficulties associated with grief, mourning, and healing during the COVID-19 pandemic. The current pandemic has affected the way individuals overcome grief, since the bereaved must grieve without the usual social, cultural, and religious supports. Due to the ban on visiting the sick in hospitals as well as gathering and mourning in funeral homes, many people are experiencing pathological grief. This article indicates the importance of pastorally accompanying people who are going through the complicated process of mourning, ${ }_{1}^{1}$ and it emphasizes that, through spiritual help and psychological accompaniment, this period can lead to healing that results in posttraumatic adaptation (resilience) and inner development. ${ }^{2}$

Key words: grief, mourning, COVID-19 pandemic, psychological aspects, pastoral accompaniment.

Grief and mourning naturally go together. Grief is an intense yearning for what has been lost that manifests emotionally, cognitively, physically, and behaviorally. Mourning is the outward expression of grief. When we lose someone we love, we need to mourn in healthy ways in order to grieve healthily. Grief is a universal phenomenon and a normal response to loss and bereavement. Manifestations of grief

$1 \quad$ See J. C. G. Corpuz, "Beyond death and afterlife: the complicated process of grief in the time of COVID-19," Journal of Public Health 43, no. 2 (2021): 281-282.

2 See R. G. Tedeschi and L. G. Calhoun, Trauma and transformation: Growing in the aftermath of suffering (Thousand Oaks: Sage Publications, 1995).

See D. Carr, K. Boerner, and S. Moorman, "Bereavement in the time of coronavirus: Unprecedented challenges demand novel interventions," Journal of Aging \& Social Policy 32, nos. 4-5 (2020): 425-431. 
can range from normal to diagnosable psychiatric conditions. ${ }^{4}$ For this reason, it is important to discuss the concept of grief.

During pandemics, people experience different types of loss. A review of literature on the experiences of grief during previous pandemics, along with what we have learned thus far during the COVID-19 pandemic, indicates that risk of complicated grief is particularly high during this time. ${ }^{5}$

\section{The nature of grief}

It is important understand the nature of grief. When a loved one dies,

Pastoral Theology grief manifests as deep sadness and a yearning to be with the person who passed away. Grief typically follows a wavelike pattern, which tends to ease over time as people adapt to their changed circumstances and regain a sense of control. Grief is unique, so there is no right way to grieve. It is important to accept that a death has occurred and to give oneself time to grieve. During this time, it is normal to experience a variety of emotions, including sadness, anxiety, loneliness, regret, anger, guilt, or a sense of not having done everything possible to prevent the person's death.

Dealing with grief means passing through different stages of bereavement. In 1969, the Swiss psychiatrist Elisabeth Kübler-Ross first introduced the five common stages of grief, popularly referred to as DABDA: Denial, Anger, Bargaining, Depression, and Acceptance, in her book On Death and Dying. ${ }^{6}$ These stages do not occur chronologically and some people who grieve may experience none of them. In addition, some people may skip one stage, while others may get stuck in another. In general, however, most people who are bereaved experience to a greater or lesser degree the following five stages of grief: ${ }^{7}$

\section{Stage 1: Denial}

Denial is the conscious or unconscious decision to refuse to admit that something is true. Denial makes it impossible to accept the news

4 See R. A. Bryant, "Grief as a psychiatric disorder," British Journal of Psychiatry 201, no. 1 (2012): 9-10.

$5 \quad$ See C. R. Mayland et al., "Supporting adults bereaved through COVID-19: A rapid review of the impact of previous pandemics on grief and bereavement," Journal of Pain and Symptom Management 60, no. 2 (2020): 33-39. of Grief Through the Five Stages of Loss (New York: Simon and Schuster, 2005). 
of a sudden loss, something unforeseen, or even something imagined. In the case of grief, it becomes impossible for the grieving person to accept death.

\section{Stage 2: Anger}

Once a person has come to terms with loss, anger manifests in an emotional or physical act by which people try to place blame. The deep pain and resentment that an individual experiences can manifest as anger directed towards others or even towards God. Not everyone goes through this stage. Anger can make the grieving person seem unapproachable to others and, paradoxically, keep others at a distance even when the grieving person needs help.

\section{Stage 3: Bargaining}

Bargaining is negotiation by which a person tries to postpone or distance himself from the loss of a loved one. With regard to grief, bargaining often entails asking a higher power or God to bring back the person who has died in exchange for something else. The grieving individual has a false belief that he can change the situation through negotiation. It is a way to seek false hope and postpone feelings of hopelessness.

\section{Stage 4: Depression}

Depression is the feeling of loss of control or hopelessness in the midst of grief. This stage occurs when the initial stages of denial, anger, and bargaining have been exhausted. As soon as a bereaved person realizes that he cannot change things, he becomes still, and the period of separation from others and isolation begins. Feelings of emptiness and loneliness become strong even when a person's family and friends surround him. Nothing seems to change this feeling of emptiness and deep sadness.

\section{Stage 5: Acceptance}

Acceptance is a feeling of inner stability and resignation in the face of circumstances that cannot be changed and the fact that the person who has died continues to live in one's memory of the heart. Acceptance occurs when the bereaved person comes to terms with reality 
Pastoral Theology

and agrees to move forward in life, which he or she sees a precious gift for him or herself and for others.

A popular misconception arose from Elisabeth Kübler-Ross' presentation of death and dying as a process with distinct stages-namely, people thought that the process of grieving took place in a series of sequential steps. In addition, there was the misunderstanding that the grieving process supposedly resolved when a person who has lost a loved one could "draw" energy from the one who had died and redirect it to relationships with those who are living. These ideas did not turn out to be true in the lives and experience of actual grieving people, who reported that they continued to experience a connection with the loved one whose passing they mourned.

Those who experience the death of a loved one often continue to grieve while also moving on with their lives. Contemporary studies involving bereaved people clearly reveal that the process of grieving is neither linear nor stage-like. Moreover, grief certainly does not "resolve" if it means letting go of one's love for the person who has died or ignoring a continual sense the deceased person's presence in the concrete reality of the physical absence that comes with death. The pastoral theologian Rogers-Vaughn noted that there is plenty of evidence that love persists beyond death among those who grieve. Grief is essentially love present in absence. ${ }^{8}$

\section{The role of funerals in mourning}

The mourning process is a protective factor against complicated grief. Funeral rites are an important part of mourning, but for those living during a pandemic, it is often impossible for these rites to take place. Funerals are an expression of pain and passage into an unknown future without a loved one. These rites are also significant for children because they help little ones to better understand the concept of death and the fact that someone they love is gone.

From the point of view of faith, funeral rites mark the end of life on earth and the beginning of life in Christ. At a funeral, the human labors of the deceased are place into God's hands, and the person who has died awaits His merciful judgment. The Christian funeral liturgy is a celebration of the Paschal Mystery of Christ the Lord. During a funeral, the Church prays that the deceased believer, who was incorporated

8

B. Rogers-Vaughn, "Recovering grief in the age of grief recovery," Journal of Pastoral Theology 13, no. 1 (2003): 40. 
into Christ's death and resurrection through Baptism, passes with Him from death to life and, duly purified in soul, will be welcomed with the saints and the elect into heaven, while the body awaits the hope of the second coming of Christ and the resurrection of the dead.

During the pandemic, the inability to grieve in the presence of family members and to see and touch the deceased have complicated the mourning phase. ${ }^{9}$ Government-imposed travel restrictions and forced separations have impaired how people can express and work through the pain of loss. Social distancing, stay-at-home orders, and limitations on the size of in-person gatherings enforced during this time have changed the way friends and family can gather and grieve. ${ }^{10}$ The risk of contagion has also necessitated that the remains of the deceased be disposed without family and friends seeing the remains and celebrating the final rites. The lack of funeral ceremonies such as face-to-face mourning and closing the coffin potentially cause survivors to feel helplessness and grieved.

To consider what a funeral is and what can take place during a pandemic, we must look at the basic elements of a funeral. If a public funeral for a loved one is not permissible due to the pandemic, or if an entire family cannot gather together, a funeral mass and burial can be broadcast on the Internet so that those who cannot be present at the burial site or prevented from gathering due to quarantine or illness can participate remotely.

To circumvent the issue of ambiguous loss, digital photos of the deceased are a viable alternative to an in-person embrace. The use of such services gives family and friends, who would have otherwise been unable to participate due to travel restrictions and/or being at high risk for contracting the infection and developing complications, the opportunity to offer their condolences and participate. ${ }^{11}$

\section{Grief during a pandemic}

The processes of loss and grief can vary in intensity and duration. Although acute grief is usually self-limiting, grief never fully ceases. Grief that remains intense and impairs individuals for more than one

$9 \quad$ J. C. Bermejo, Duelo Digital (Bilbao: Desclée De Brouwer, 2020).

10 See M. J. Byrne and D.R. Nuzum, "Pastoral closeness in physical distancing: The use of technology in pastoral ministry during COVID-19," Health and Social Care Chaplaincy 8, no. 2 (2020): 206-217.

11 See I. Muturi, S. Freeman, and D. Banner, "Virtual funerals: A feasible and safer option during the COVID-19 pandemic," Journal of the American Geriatrics Society 68, no. 11(2020): 2472-2473. 
Pastoral Theology

year is considered prolonged grief disorder ${ }^{12}$ (PGD) or complicated grief $^{13}(\mathrm{CD})$, both of which are described as an intense and extended form of persistent yearning and grief that impairs individuals by making them indefinitely unable to process the loss and move on in life. ${ }^{14}$ Risk factors for complicated grief are a sudden and unexpected death, ${ }^{15}$ witnessing a difficult death, and an inability to let go of the person who has passed away. ${ }^{16}$

Deaths due to COVID-19 have been labeled negative deaths as they are marked by physical and psychological suffering, physical separation from family members, lack of preparation for death, disrespectful treatment, unwanted medical interventions, an inability to access medical services, sudden disease progression, and sometimes unexpected patient death.

When faced with a major loss such as the death of a loved one due to COVID-19, those left behind often imagine "alternative scenarios;" in other words, they almost automatically think about what could have been different so that the person would not have died. This is called counterfactual thinking, and it is a natural reaction to a significant loss even when the rational mind realizes that alternative scenarios are not real. This is one way that individuals cope with the acute pain of loss. Under ordinary circumstances, these thoughts are not as prominent. They can be more intense and more difficult to resolve, however, when a loved one dies in a sudden and unexpected way. In the case of

The condition of persistent grief known as Prolonged Grief Disorder (PGD) was recently included in the International Classification of Diseases (ICD-11). See: World Health Organization, "2020 International statistical classification of diseases and related health problems," https://icd.who.int/.

13 M. C. Eisma, R. Rosner, and H. Comtesse, "ICD-11 Prolonged grief disorder criteria: Turning challenges into opportunities with multiverse analyses," Frontiers in Psychiatry 11 (2020): 752.

14 Grief therapy, which facilitates grief management, may act as a template for developing a specific intervention for complicated grief. Complicated grief psychotherapy (CGT) is the best-studied intervention for prolonged and recalcitrant grief disorders. It facilitates progression through stages of mourning and checks for any derailments. CGT has been found to be more effective than interpersonal psychotherapy and antidepressants. See J. S. Goveas and M. K. Shear, "Grief and the COVID-19 pandemic in older adults," American Journal of Geriatric Psychiatry 28, no. 10 (2020): 1119-1125.

15 S. Nakajima, "Complicated grief: Recent developments in diagnostic criteria and treatment," Philosophical Transactions of the Royal Society of London. Series B, Biological sciences 373, no. 1754 (2018): 20170273.

16 See E.van Ee, "Samen rouwen: over sociale steun aan nabestaanden gedurende de COVID-19-pandemie," Tijdschrift voor Psychiatrie 63, no. 1 (2021): 13-15. 
COVID-19, it is very easy to imagine alternatives! For example, people may question: "What if the deceased person had not gone where he did? Maybe he would not have gotten infected? If he had not gone to that particular supermarket, attended that party, or traveled to that location, then he would not have been exposed to the virus!" This type of thinking can occur even if it is unclear where or how the person contracted the virus. The ease of imagining alternative scenarios can sometimes make it more difficult for people to accept reality as it is and increases their risk for PGD.

The natural process of bereavement can be disrupted further when some of the complexities of bereavement go unresolved. A variety of factors may be at play in this type of situation, including the bereaved person's characteristics, the dynamics and nature of the person's relationship with the deceased loved one, and the circumstances and context of the death. These factors increase the possibility that one or more aspects of the meaning or experience of pain will disrupt the person's bereavement and adaptation to a new reality.

Another component is that the bereaved person may not have had the opportunity to say goodbye to his family member, leaving many words unspoken and things unresolved. The inability to be at the person's side as she die can increase the grieving person's sense of disbelief and make it more difficult to accept that the death actually happened.

Social distancing related to COVID-19 impacts the grieving process significantly in several ways. Social distancing has affected religious and cultural aspects of the mourning process, depriving those who mourn of the comfort of community support and ritual. Especially at the beginning of the pandemic, but even now, people often could not be present with loved ones while they were dying. This generated a series of emotional reactions in the survivors.

In the case of COVID-19, the circumstances surrounding the person's death increase these reactions. For example, knowing that the deceased person suffered and died alone is distressing and can increase feelings of personal guilt. Survivor's guilt, which is a common, is the sense of distress at being spared from the hardship that the deceased person endured. Such guilt is often manifested in the question: "Why was I spared while he or she died?"

Sometimes the sheer number of deaths that have occurred in a given family leads to a lack of recognition of each member's grieving experience. Society often overlooks or downplays the death of those who are chronically ill, especially the elderly. When such repressed emotions 
are not treated properly due to a lack of adequate resources and financial constraints following the pandemic this can produce devastating emotional effects in the future. The above factors can cause what is known as disenfranchised grief and interfere in a person's ability to cope. All of these factors have increased the possibility of prolonged bereavement disorder arising during the COVID-19 pandemic. ${ }^{17}$

\section{Strategies to pass through the mourning process}

To help individuals better understand the difficult journey of grief, Dr. William Worden developed four tasks of mourning. ${ }^{18}$ It is impor-

Pastoral Theology tant to note that many people experience loss or its intensity in their own way. This experience is not linear and every person's journey is unique. However, the steps that take place in the process of grieving and healing are similar and include the following tasks:

- To accept the reality of loss. While the final stage of Kubler-Ross' model is acceptance, Worden believes that acceptance of the reality of the loss and death is the foundation of healing. There are a couple of ways to start this process. Seeing the body of the person who died is one way. Participating in rituals such as planning the funeral, preparing the eulogy, or caring for the gravesite are ways to begin this first task. Turning to spirituality or religion can also foster quicker acceptance.

- To search for a personal way to express grief. Many people have different and often unique ways of dealing with their pain. Some need to talk, some cry, others keep busy with work or a hobby. Some people cope with the sudden pain of loss by finding a way to commemorate the person who died by investing in a cause close to their loved one's heart or by helping other similar groups of survivors. It is appropriate to process pain through action as long as the aim is to navigate one's way through the pain and not to avoid it or hide from it.

- To adjust to the world without the deceased person. It is important to point out that different people adapt to new realities in different ways. In the case of the death of a loved one, for example, this could mean removing the person's phone number from one's

17 See C.K. Kokou-Kpolou, M. Fernández-Alcántara, and J. M. Cénat, "Prolonged grief related to COVID-19 deaths: Do we have to fear a steep rise in traumatic and disenfranchised griefs?" Psychological Trauma: Theory, Research, Practice, and Policy 12, S1 (2020): 94-95.

18 J. W. Worden, Grief Counseling and Grief Therapy: A Handbook for the Mental Health Practitioner, Fourth Edition (New York: Springer, 2009). 
address book or making new life plans without the deceased. Either way, the survivor must start living in a new world without the deceased's affection.

- To find an enduring connection with the person who died in the years to come. Many people may find themselves exploring how to remain emotionally connected with the deceased while simultaneously moving forward in their lives. It is important to note that that this does not entail forgetting the deceased but of shifting one's attention from the past to the present and then to the future. Worden points out that there is no fixed time frame in which to complete this task; this period, however, often lasts for months and years, rather than days or weeks. Bonding with the deceased person through prayer or, in the case of non-believers, taking time to write in a journal and acknowledge the things about the deceased for which one is grateful are helpful.

\section{The Christian meaning of death}

The Christian faith-filled response to death is Christ's birth, death, and resurrection. Jesus did not articulate a theory on pain and death; $\mathrm{He}$ did not explain the reason for these human realities. Instead, $\mathrm{He}$ experienced and lived out in Himself all of the suffering of the world and accepted to die in anguish like all men. He did not immediately say that pain is valuable; rather, Christ taught that it is wrong to reject God and His faithful love for man when one experiences pain, illness, and death. In Christ we can interpret the complete meaning of every person's life and death. Without physical death we would not be able to access real life: the encounter with God.

Physical, earthly life is important, but it is not the end. Early life entails joys and sorrows, health and sickness, but it is always precious as the path to divine, eternal life. Beyond the final obstacle that is death, salvation-the triumph over man's creaturely condition as well as full and definitive life in God-awaits. All of this is possible because Jesus became man like us. He took on our sufferings and diseases, and $\mathrm{He}$ experienced human tragedy and helplessness in the face of death. He cried out from the cross to God and abandoned Himself to the Father with the utmost confidence. In His acceptance of death, Christ saved man and triumphed over death, giving us hope for the impossible and faith in His Paschal Mystery: "I am the resurrection and the life; whoever believes in me, even if he dies, will live; whoever lives and believes in me will never die" (Jn 11:25-26). By participating in the suffering 
Pastoral Theology of Christ, the one who believes knows that he also participates in the fullness of Christ's life as the Risen One.

Through His passion, Jesus not only frees us from the radical evil of death, sin, and every other misery, but $\mathrm{He}$ also gives meaning to every suffering, which is a sign and instrument of salvation. He died for everyone; no one is rejected by God's love for Him. ${ }^{19}$ Death is the very place of love and hope. From the point of view of faith, death becomes a mysterious experience rather than a simple problem to manage. Living it humanly involves the utmost respect for the dignity of the human person; a "meditatio mortis" is transformed into an understanding of the ultimate value of life in view of its end in the midst of the dynamism of hope. ${ }^{20}$ Death gives life its ultimate meaning. Characterizing death entails doing what is necessary to make others understand that the dying process is a dimension of life. ${ }^{21}$ Seen through the lens of faith, the Christian claim that love is stronger than death (cf. Song of Songs $8: 6-7)$ is proven true. The loss is real, as is the suffering that it generates, but the bonds of love are not broken by loss.

An ongoing sense of connection with the deceased or with a lost experience does not mean that the bereaved person cannot invest in life. Rather, he acknowledges that life has changed forever due to loss and, yet, life still goes on. In situations of death, then, the bond and process of closure are endless. There is the certainty of both the end of physical life and the love that continues even after death. In situations of less tangible loss, such as death from COVID-19, pain involves processing the loss of hopes and those things that give life meaning. Such desires surely express love in the midst of pain. It does not seem a stretch for Christians to reorient themselves away from the idea that suffering must be resolved and put aside toward recognizing that pain manifests love, that all authentic love is of God, and that nothing-not even death-can separate us from God's love in Christ Jesus.

Overcoming the fear of the pain caused by death begins with an awareness of one's own fragility, which we all experience so strongly during the pandemic, and accepting that we depend on God, Who ultimately reveals Himself as Love and Mercy.

19 See Discorsi, Messaggi, Colloqui del Santo Padre Giovanni XXIII, Vol. V (Città del Vaticano: Libreria Editrice Vaticana, 1964), 618.

20 See J. C. Bermejo, La esperanza en Tiempo de Coronavirus (Santander: Sal Terrae, 2020).

21 See J. C. Bermejo, M. Magaña, "Modelo Humanizar" de Intervención en Duelo (Madrid: Sal Terrae, 2014). 


\section{Pastoral accompaniment during the COVID-19 pandemic}

Life in the midst of a pandemic reconfigures the way we approach the problem of loss theologically. Mourning is the bodily, cognitive, emotional, and spiritual process through which we deal with the loss of something or someone significant. It is the soul's cry of protest against broken ties and severed connections. It is the body's appeal of resistance to the terror of being existentially alone. For creatures whose very beings require relationships, connections, and community, pain is part of the struggle to relearn how to be fully human in the face of loss, and the coronavirus has, unfortunately, allowed us to experience considerable bereavement.

Faith communities have developed centuries of wisdom to help people cope with death, dying, and pain. Yet, the sheer scale of the COVID-19 contagion and death in the last year defies the imagination and easily overwhelms even those who are accustomed to it. In many cases, death due to COVID-19 occurs quickly, but the most troubling component of the pandemic is that so many people have died alone or in the presence of only one healthcare worker. They are isolated from the comforting presence of family members and faith communities.

Although the Catholic Church knows how to be a witness to the loving presence of God when confronted with another's suffering, She is prevented from doing so fully and in the usual ways. This not only affects those who are dying but also greatly distresses their family members and healthcare workers. In light of this disaster, every concrete gesture, even the most humble and seemingly irrelevant, is very valuable! In this particular circumstance, death can teach us to accompany others during their own death and be present to those who are in the process of mourning. ${ }^{22}$

Accompanying others in dying, even by telephone or video call, can teach us to live because it involves valuable gestures that can be easily relegated to everyday life, gestures evoked more by feeling than by reason, gestures base on values that demand relationship and accompaniment. Accompanying others in the process of dying reveals the value of our silent presence, the value of the metaphorical embrace, and the value of an outstretched hand that has replaced the now impossible caress. ${ }^{23}$ It reveals the power of small and simple gestures, the need for the symbolic to survive, to continue living.

$22 \quad$ See V. Paglia, La hermana muerte. La dignidad del vivir y del morir (Santander: Sal Terrae, 2017), 43. 


\section{Conclusions}

The COVID-19 pandemic is still affecting individuals across countries and cultures, and the death toll continues to rise. As of September 30,2021 , there have been 233,136,147 confirmed cases of COVID-19 globally, including 4,771,408 deaths reported to the World Health Organization. ${ }^{24}$

In addition to the undisputed direct effect of the pandemic on mental health worldwide, this article seeks to highlight the secondary impact of the death of loved ones due to this disease, the consequences of which are likely to be felt in the coming months and years.

The death of a loved one is a major life stressor and often described

Pastoral Theology as one of the most painful experiences that a person will undergo in his lifetime. ${ }^{25}$ During the pandemic the grieving process of the sudden death of a loved one has become complicated by all the restrictions caused by COVID-19. This article points out the importance of psychologically accompanying the bereaved so that they can avoid developing complicated grief ${ }^{26}$ and of the consoling value of pastoral accompaniment, which helps the grieved to continue living, to reconnect with others and life with a sense of purpose and meaning, and to find ways to honor the deceased loved ones and keep their memory alive within the heart.

Accompaniment demonstrates that much can and must be done to help the bereaved. Participating in such "joys and hopes, the grief and anxieties of the people of this age, especially of those who are poor or in any way afflicated" is the call of those who follow Christ. For, "[i]ndeed, nothing genuinely human fails to raise an echo in their hearts." 27

\section{Bibliography}

1. Bermejo, J. C. Duelo Digital. Bilbao: Desclée De Brouwer, 2020.

2. Bermejo, J. C. La esperanza en Tiempo de Coronavirus. Santander: Sal Terrae,2020.

${ }_{24}$ See WHO, https://covid19.who.int/

25 See G.A. Bonanno and S. Kaltman, "Toward an integrative perspective on bereavement," Psychological bulletin 125, no. 6 (1999): 760-776.

26 See G.A. Bonanno, "Loss, Trauma, and Human Resilience: Have We Underestimated the Human Capacity to Thrive After Extremely Aversive Events?" American Psychologist 59, no. 1 (2004): 20-28.

27 See Second Vatican Council, Gaudium et Spes [Pastoral Constitution on the Church in the Modern World], accessed January 10, 2021, https:// www.vatican.va/archive/hist_councils/ii_vatican_council/documents/ vat-ii_const_19651207_gaudium-et-spes_en.html. 
3. Bermejo, J. C., and M. Magaña. "Modelo Humanizar" de Intervención en Duelo. Madrid: Sal Terrae, 2014.

4. Bonanno, G. A., and S. Kaltman. "Toward an integrative perspective on bereavement." Psychological Bulletin 125, no. 6 (1999): 760-776.

5. Bonanno, G. A. "Loss, Trauma, and Human Resilience: Have We Underestimated the Human Capacity to Thrive After Extremely Aversive Events?" American Psychologist 59, no. 1 (20041): 20-28.

6. Bryant, R. A. "Grief as a psychiatric disorder." British Journal of Psychiatry 201, no. 1 (2012): 9-10.

7. Byrne, M. J., and D. R. Nuzum. "Pastoral closeness in physical distancing: The use of technology in pastoral ministry during COVID-19." Health and Social Care Chaplaincy 8, no. 2 (2020): 206-217.

8. Carr, D., K. Boerner, and S. Moorman. "Bereavement in the time of coronavirus: Unprecedented challenges demand novel interventions." Journal of Aging \& Social Policy 32, nos. 4-5 (2020): 425-431.

9. Corpuz, J. C. G. "Beyond death and afterlife: the complicated process of grief in the time of COVID-19." Journal of Public Health 43, no. 2 (2021): 281-282.

10. Discorsi, Messaggi, Colloqui del Santo Padre Giovanni XXIII, Volume V. Città del Vaticano: Libreria Editrice Vaticana, 1964.

11. Eisma, M. C., R. Rosner, and H. Comtesse. "ICD-11 Prolonged grief disorder criteria: Turning challenges into opportunities with multiverse analyses." Frontiers in Psychiatry 11 (2020): 752-758.

12. Goveas, J. S., and M. K. Shear. "Grief and the COVID-19 pandemic in older adults." American Journal of Geriatric Psychiatry 28, no. 10 (2020): 1119-1125.

13. Kokou-Kpolou, C. K., M. Fernández-Alcántara, and J. M. Cénat. "Prolonged grief related to COVID-19 deaths: Do we have to fear a steep rise in traumatic and disenfranchised griefs?" Psychological Trauma: Theory, Research, Practice, and Policy, 12, S1 (2020): 94-95.

14. Kübler-Ross, E., and D. Kessler. On Grief and Grieving: Finding the Meaning of Grief Through the Five Stages of Loss. New York: Simon and Schuster, 2005.

15. Kübler-Ross, E. On Death and Dying. New York: Macmillan, 1969.

16. Mayland, C. R., A. J. E. Harding, N. Preston, and S. Payne. "Supporting adults bereaved through COVID-19: A rapid review of the impact of previous pandemics on grief and bereavement." Journal of Pain and Symptom Management 60, no. 2 (2020): 33-39.

17. Muturi, I, S. Freeman, and D. Banner. "Virtual funerals: A feasible and safer option during the COVID-19 pandemic." Journal of the American Geriatrics Society 68, no. 11 (2020): 2472-2473.

18. Nakajima, S. "Complicated grief: Recent developments in diagnostic criteria and treatment." Philosophical Transactions of the Royal Society of London: Series B, Biological Sciences 373, no. 1754 (2018): 20170273.

19. Paglia, V. La hermana muerte. La dignidad del vivir y del morir. Santander: Sal Terrae, 2017. 
20. Rogers-Vaughn, B. "Recovering grief in the age of grief recovery." Journal of Pastoral Theology 13, no. 1 (20031): 36-45.

21. Second Vatican Council. Gaudium et Spes [Pastoral Constitution on the Church in the Modern World]. Accessed January 10, 2021. http://www. vatican.va/archive/hist_councils/ii_vatican_council/documents/vatii_const_19651207_gaudium-et-spes_en.html.

22. Tédeschì, R. G., and L. G. Calhoun. Trauma and transformation. Growing in the aftermath of suffering. Thousand Oaks: Sage Publications, 1995.

23. Van Ee, E. "Samen rouwen: over sociale steun aan nabestaanden gedurende de COVID-19-pandemie." Tijdschrift voor Psychiatrie 63, no. 1 (2021): 13-15.

24. Worden, J. W. Grief Counseling and Grief Therapy: A Handbook for the Mental Health Practitioner, Fourth Edition. New York: Springer, 2009. 